\title{
総 説
}

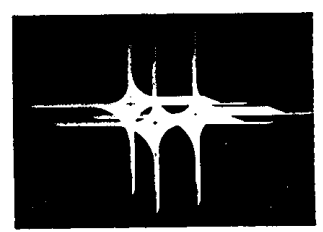

\section{特集：生理機能検査装置の課題と将来}

心電 図検 査 装 置

阿部哲 朗*

\section{1.はじめに}

ここでは安静時心電図検査などに使用される 標準12誘導心電計, 長時間心電図検査に使用さ れるホルタ一心電計, 負荷心電図検查に使用さ れるストレス心電計について述べる.

心電図検查装置は早い時期から臨床の場で広 く使用されている装置である。しかし，心電図 学の発展, 技術の進歩とともに変化していく必 要があり, 以下に心電図検査装置に共通する課 題を示す.

1 ) 心電図学の進歩に合わせ，診断に有効な 機能を取り込むこと。

心電図の対象周波数・振幅を拡大した，心 室遅延電位 (late potential) などの微少 振幅心電図， $\mathrm{R}$ 一 Rゆらぎなどの研究が臨 床に展開されている。これらを含む新しい 計測機能を取り込む。

2）計測・解析の精度を向上させ，診断によ り有効な検查が行えること。

各心電図検查装置子も計測・解析機能を持 っているが，さらに精度の改良が求められ ている。ファジー理論などを用い，計測・ 解新精度を向上させる。

3）より安定した検查が容易に行えること。 電極, 誘導コードの改良による心電入力の 安定化，デジタル信号処理の改良による記 録, 計測の安定化, 不良信号の自動諗識,
表示機能の有効利用，ユニーザインターフェ イスの改善なぞ.

4 ）被検者の負担を少なくすること. 被検者が携帯するホルター記録器の小型・ 軽量化，12誘導心電入力部のコードレス化 など。

5 ) 総合診断, 検查作業の効率化に有効であ ること.

生理検査システムと接続でさ, データファ イリング，オーダリング，他の生理検査装 置との連携を可能にする.

次に, 標準12誘導心電計, ホルター心電計, ストレス心電計に分けて，個別の課題について 示す。

\section{2. 標準 12 誘導心電計}

標準12誘導心電計は使用目的に合わせ多様化 してきており，今後ますます用途に合った形に 変化すると考克られる。

高機能化では，信号処理能力を高め心電図学 の進歩に合わせた新しい計測, 解析手法を取り 込んだ高精度心電計と，ホルター，ストレス等 の機能を取り込んだ総合心電図検查装置となる。

往診、検診 (学童・成人病など) 用途では, 小型・軽量化が進む. 更にファイル機能の信頼 性向上により記録紙への記録機能を持たないペ ーパレス心電計も実現される.

検査室で使用される心電計では, 生理検查デ ーヌファイルシステムと密結合され, 心電計か ら，過去の心電図を含む他の生理検查データを 
参照可能となるシステムとなる，また，ここで もペーパレス化は進み, 記録はデータファイル システムで一括管理される装置も考光られる。

\section{3. ホルター心電計}

ホルター心電計は, 被検者が携帯し, 通常 24 時間の心電図を連続して磁気テープなどに記録 する記録器（携帯型心電計）と，その心電図を 後で高速に再生・解析する解析装置（高速再生 処理装置)で構成される.

長時間の心電図を連続して記録・解析出来る ことにより, 一過性の不整脈, 虚血性心疾患の 診断, 経過観察, 薬効評価などに有効であり, 10年汪ど前より臨床の場で多く使用されるよう になった。

\section{1 記録器（携帯型心電計）}

記録器は，磁気テープを使用し 2 誘導の心電 図を24時間連続に記録するものが主流である。 コンパクトカセットを使用する装置が多いがオ ープンリール，マイクロカセットを使用するも のも一部ある。また記録媒体として，I C×モ リ，ハードディスクを使用する装置や記録器で 心電図の解析を行らリアルタイム型の記録器も ある。

磁気テープを使用した記録器は，かなり完成 された装置となっており，記録の保管が容易で あることから日常臨床での使用には最適な装置 であるが，磁気テープヘのアナログ信号記録で あることに起因する限界が指摘されている。小 型軽量化の要望に対しては，現状の製品は，磁 気テープの大きさよりほ注限界に近くなってい る。また，磁気テープの記録特性による記録歪 の解消, 記録心電誘導数の増加, 記録パラメー タの増加，より長時間の記録への対忍は困難で ある。ささらには可動部を持つことによる定期的 な保守の必要性についても改善が必要な項目と なっている。

これらの課題に対する解決策として期待され るのが，I Cメモリ，ハードディスクなどを用 いたデジタル信号記録である。これらの記録媒 体は著しい早さで進歩して赦り，大ささ，価格 でホルター記録器に使用出来る状況となってい る。また，今後もさらに進歩し，小型化，記録
容量の増大が進むと考えられる。

1980年代より I C メモりを使用した間欠記録 式の装置が製品化されている，その後, 㴼波 形十間欠拉大波形, 波形歪みの多いデータ压縮 法を使用した装置などが製品化されたが，臨床 現場からの要求とは差異がある。一昨年あたり からやっと, 磁気テープ記録器の性能を越光る 装置が製品化されだした。これは，記録媒体の 容量増加に起因している.

現状では, 大きさ, 重量, 価格の点でデジタ ル記録器の磁気テープ記録器に対する優位性が 十分ではないが，心電波形の記録歪み，保守の 容易さでは優れている。

今後さらに記録容量の増大が可能となれば, 心電計々同等な周波数特性, 12 誘導心電図ホル ターが，小型軽量で実現できる。また，検查時 間の長時間化についても可能となるが，生体へ の影響が少ない長時間使用可能な電極の開発が 必要である。また小型化技術の進歩もあり，そ の他の生体信号の同時記録が容易となる．既に 血圧, 呼吸, 脳波, 体位, 運動量などがホルタ 一として開発されているが，今後さらに多くの パラメータが実現可能となる。

\section{2 解析装置 (高速再生処理装置)}

解析装置は, 記録時の60倍から1,000倍の高速 再生を行う。以前は, 心電波形を再生時にブラ ウン管上で重疊表させ, 同時にスピーカから $\mathrm{R}-\mathrm{R}$ 間隔の変化を音程の変化として出力, 解 析者が視覚と聴覚の両方で異常波形を検出する AVSEP 方式が主流でめった。しかし現在では， コンピュータによる不整脈の自動検出, S Tレ ベルの計測を行う装置が主流となり解析者の負 担の減少に役立っている。しかし, 現状では自 動解析の精度が十分ではなく, 解析者の確認, 装置との対話形式による編集, 再解析作業が必 要な場合が多い。

コンピュータの性能の進歩により，自動計測 ・検出の進歩が著しいが, 精度, 機能の点でよ り一層の改善が望まれている。不整脈の解析に 招いて現状ではP 波の解析が不十分であるが， ホルター解析に置けるP波認識の研究も進んで おり，近い将来この問題点も解消寸ると考光ら れる。 


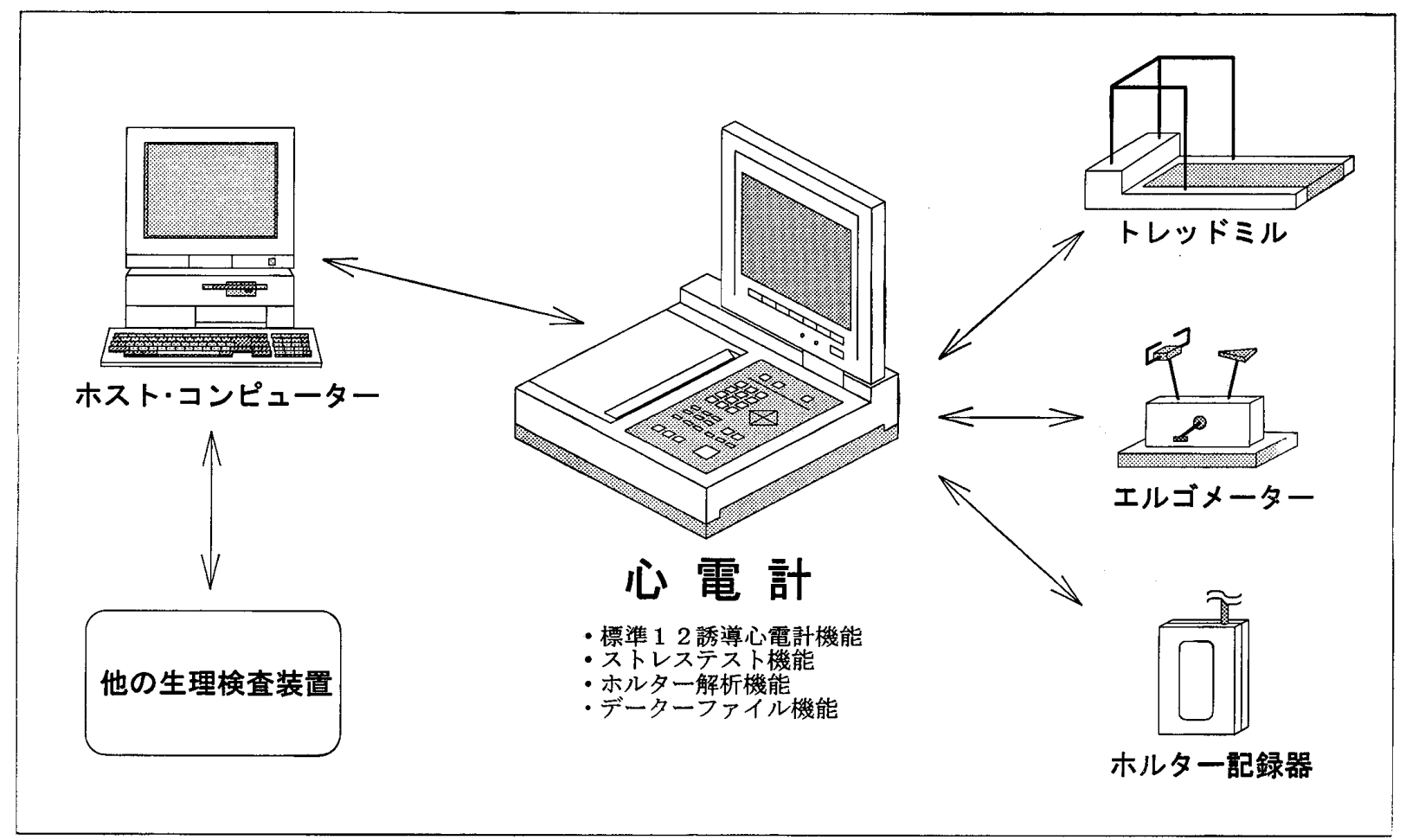

図 1

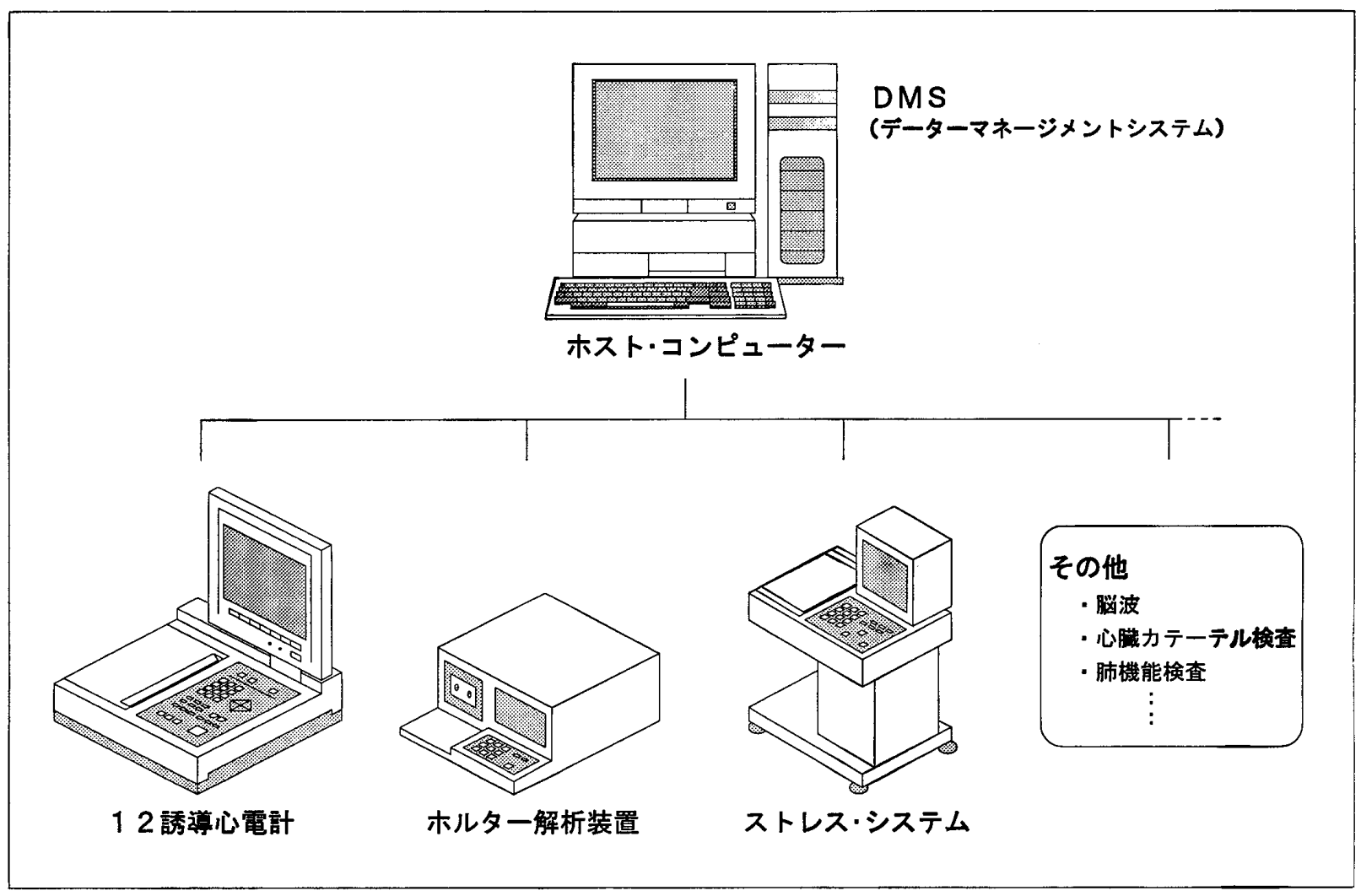

図 2

リアルタイム解析型の記録器では, 解析装置 は単なる再生機能だけでよいが，編集機能汇制 限があり, 再解析が出来ないものが多く, 解析 機能の精度向上がより強く求められる。

\section{4. ストレス心電計}

従来, ストレス心電計は, 冠動脈疾患の重症 度の診断や不整脈の誘発を目的とした運動負荷 
心電図検査に用いられてきた。しかし，最近は， 冠動脈疾患患者に和汀る運動療法, 運動処方, 健常者のメディカルチェック，体力診断などに も幅広く使用されるよらになってきた。

メーカーの立場から，ストレス心電計の最大 の課題は，欧米に比較し負荷心電図検查の検査 件数が少ないことである。これは，システム全 体の規模が大きいこと，検查に危険が伴うこと， 検查の所要時間が長いこと, 健常者に対するメ ディカルチェックが少ないことによる.

近年, 12誘導心電計にストレステスト機能が 付加されたものが製品化され，本体は小型にな ってきているものの, 負荷装置 (トレッドミル やエルゴメーター）の大きさには変化がなく， 一般開業医での施行は難しい現状である，検查 に伴う危険性の減少に対しては，検查担当者の 負担を少しでも減らすためにアラーム機能（心 拍数， S Tレベル，不整脈，血圧值）の強化・ 充実が望まれる。検查にかかる所要時間の低減， 被検者に対する負担，検查のしやすさより12誘 導心電計の入力部が無線（電波または赤外線通 信）でワイヤレス化された装置が海外で製品化 され出している.

また, メディカルチェックでの使用に対して は，スクリーニング用運動負荷自動診断が付い た装置による検査件数の増加を期待する。

ストレス心電計に打いても，使用目的の多様 化に合わせ，各用途にあった使い易さ，計測機 能を持つ装置にさらに分化していくと考兄られ る.

\section{5. おわりに}

最近, コンピュータ, 通信, 画像処理技術な ぞの進歩が非常に早く，それらを統合した成果 としてのマルチメディアが話題になっている.
技術的側面から見れば心電図検查装置もこれら の成果を取り入れていくと考兄られる.

標準 12 誘導心電計, ホルター心電計, ストレ ス心電計に分けて述べたが，将来的にはそれぞ れの検查目的に合致した単独装置と, 以下に示 す 2 つのシステム化された装置に統合されてい くと思われる.

1 つは, 標準12誘導心電計, ホルター心電計, ストレス心電計が統合された装置にデータファ イル機能が取り込まれ，ホストコンピュータと の通信機能を持ち小規模なデータマネージメン トが構成可能なシステムである，専門医，小病 院などで主に使用されると考えられる（図 1).

もう 1 つは, 標準 12 誘導心電計, ホルタ一心 電計, ストレス心電計等, それぞれの単独装置 が，データマネージメントシステムと高速通信 機能で密結合されるもので, 大病院などの生理 検査室で多く使用されると考兄られる（図 2 ）.

将来的には，このようなシステム化された姿 を示すことになるが，心電図検查装置の基本は， 被検者への負荷が少なく，容易に，安定した， 診断に有効な心電図データを記録できることで ある、今まで以上に, 臨床の立場からの視点を 重視し, より効果的な心電図検査装置となるこ とが必要である。

一方, 心筋梗塞の急性期に冠再環流療法が積 極的に施行されるようになり，本治療の施行時， 及び施行後の経過観察に12誘導心電図の監視・ 計測が有用であると言われている，既に，心臓 カテーテル検査装置や患者監視装置に12誘導心 電図機能が取り达まれたものも製品化されてい る、このことょり, 生理検査装置の一つとして の12誘導心電図から治療や監視分野への発展性 も期待できる。 